\title{
Using Nonperforming Loan Ratios to Compute Loan Default Rates With Evidence From European Banking Sectors
}

\author{
Dobromił Serwa* \\ *Institute of Econometrics, Warsaw School of Economics \\ Financial Stability Department, Narodowy Bank Polski
}

Submitted: January 28, 2016 • Accepted: May 17, 2016

\begin{abstract}
This research is the first attempt to calibrate default rates of loan portfolios using raw data on nonperforming loans and some additional information on the maturity structure of the loan portfolios. We applied a simple model of loan quality, controlling for loan maturities and dynamics of loan supply. Results for nine national aggregate indices of nonperforming housing loans in the Czech Republic, Greece, Ireland, Hungary, Latvia, Poland, Portugal, Romania, and Spain revealed strong differences in the dynamics of calibrated default probabilities between countries. Calibrated default rates were correlated with macroeconomic factors, but the linkages depended on the markets investigated.
\end{abstract}

JEL classification: C15, C22, G21, G31

Keywords: NPL ratio, default rate, credit growth, housing loans, European banking sectors

${ }^{*}$ Corresponding Author. Email: dserwa@sgh.waw.pl 


\section{Introduction}

This paper suggests a simple method to derive default rates (DR) of loan portfolios from the time series of nonperforming loans (NPL). The NPL ratio (i.e., the ratio of NPLs to total loans in the portfolio) is a standard measure of loan quality widely used in research analyzing performance of banking sectors and their customers (e.g., Meeker and Gray, 1987; Lízal and Svejnar, 2002; Hasan and Wall, 2004; Podpiera, 2006; Mendoza and Terrones, 2008; Aman and Miyazaki, 2009; Festić et al., 2009; Čihák and Schaeck, 2010; Whalen, 2010; Jin et al., 2011). The well-known problem of this measure is the mechanistic dependence of its values on the rate of growth of the loan portfolio, which often forbids cross-sectional and inter-temporal comparisons (Tornell and Westermann, 2002, p. 22; Coricelli et al., 2006). Another drawback of the NPL rate as a measure of loan quality is that it is a backwardlooking variable (i.e., it evaluates the historical performance of the loan portfolio). NPLs often remain in portfolios for several quarters or even years, affecting the NPL ratio but having no effect on the current financial performance of credit institutions. In contrast, most analysts are interested in the present standing of the portfolio and the present performance of the debtors. The DR is one alternative variable that describes the current performance of loans and does not automatically depend on the dynamics of the loan.

The DR quantifies the rate at which borrowers default on the amount of funds they owe to the bank in a given (e.g., most recent) period. The DR is often weighted with the values of analyzed loans so that defaults of large loans weigh more in this measure. The historical DR may be used to predict further credit risk, and this is known as the probability of default (PD). Therefore, DRs are often used to predict values of loan portfolios. One important problem is the lack of publicly available data on the PDs and DRs of loan portfolios, while the time series of NPL ratios at the aggregate country level are published by international central banks and financial supervisory authorities.

The literature bears witness to just a few attempts to construct a DR of some loan portfolios using information contained in the NPL ratio. Pinto and Vivan (2013) constructed the implied NPL ratio, a new measure that controlled the changes in the portfolio growth rate during its average term to maturity. This measure took into account differences in the default distribution across time and the amount of time a past due loan remained in the balance sheet. Serwa (2013) derived another measure of loan quality: the adjusted NPL rate. This measure was similar to the DR because it was also robust to changes in the rate of growth of the loan portfolio.

This paper contributes to the literature by deriving the DR from the information contained in the NPL ratio. Moreover, we applied this measure in the analyses of stability in the aggregate loan portfolios in nine European banking sectors. We applied a simple method to calibrate the term structure of the loan portfolios proposed by Serwa (2013) and derived the time series of DRs from historical data of NPL rates in the Czech Republic, Greece, 
Ireland, Hungary, Latvia, Poland, Portugal, Romania, and Spain. We found that the derived PDs for some countries provided valuable information about the state of the banking sector. However, for other countries we found the need for a better calibration of the method.

We focused here on the aggregate portfolios of housing loans because these loans are relatively uniform in comparison to other types of banking loans. The housing loans are long-term contracts, and something such as a bad quality mortgage can remain in the loan portfolio for a long period of time and have an influence the NPL ratio. Analyzing the aggregate DRs of housing loans provided valuable information about the average financial performance of households involved in mortgages.

The next section describes the method to calibrate the DRs, given minimum information on the term structure of the loan portfolio. Section 2 includes empirical results of estimated DRs for nine country-aggregates of housing loans, and the final section involves our conclusions.

\section{Term-structure of loans and default rates}

Our description of the model of a loan portfolio strictly followed Serwa (2013). Let $n$ be the maximum maturity of a loan contract in a given portfolio. The loan portfolio $\boldsymbol{X}_{t}$ at time $t$ consists of aggregated loan cohorts $x_{i, j, t}$ supplied to borrowers $i$ periods ago and maturing in $j$ periods, where $i=0,1, \ldots, n-1$ and $j=1,2, \ldots, n$, respectively. The NPLs are a part of this portfolio and the aggregated bad-quality (non-performing) loan cohorts are denoted as $b_{i, j, t}$. The tranches of good-quality loans $g_{i, j, t}$ are computed as $g_{i, j, t}=x_{i, j, t}-b_{i, j, t}$.

The NPL ratio is the share of bad loans in the portfolio:

$$
N P L_{t}=\frac{\sum_{i=0}^{n-1} \sum_{j=1}^{n} b_{i, j, t}}{\sum_{i=0}^{n-1} \sum_{j=1}^{n} x_{i, j, t}} .
$$

The following simplifying assumptions were introduced in order utilize the derivation of DRs. The important characteristics of loan contracts do not change while loans are present in the analyzed portfolio. Loans are only removed from the portfolio after reaching maturity. Good-quality loans pay interest while the NPLs do not. The interest paid on loans in each

period is not included in the portfolio, and all new loans added to the portfolio at time $t$ are of good quality. The good-quality loans are repaid by borrowers in equal tranches between each period, $g_{i, j, t} / j$, and the bad-quality loans are not repaid until maturity. Calculations assuming other repayment schedules do not change our general results, the above assumptions are the same as in Serwa (2013).

The recursive formula for the value of NPLs is as follows:

$$
b_{i, j, t}=b_{i-1, j+1, t-1}+D R_{i-1, j+1, t-1} \cdot g_{i-1, j+1, t-1},
$$


where $D R_{i-1, j+1, t-1}$ is the average default rate between time $t-1$ and $t$ for the loans that have belonged to the portfolio since $i-1$ periods and have been expected to mature in $j+1$ periods at time $t-1$. Because we aimed to construct a single index of DR, we computed an average DR for all cohorts of loans. To simplify computations, we assumed that $D R_{i, j, t}=D R_{t}$ was the same for all maturities and cohorts at time $t$. Now, the aggregate value of all NPLs is equal to the following:

$$
\sum_{i=0}^{n-1} \sum_{j=1}^{n} b_{i, j, t}=\sum_{i=0}^{n-1} \sum_{j=1}^{n-1} b_{i, j, t-1}+D R_{t} \cdot \sum_{i=0}^{n-1} \sum_{j=1}^{n-1} g_{i, j, t-1} .
$$

Also, the aggregate value of good-quality loans is equal to the following:

$$
\sum_{i=0}^{n-1} \sum_{j=1}^{n} g_{i, j, t}=\sum_{j=1}^{n-1} g_{0, j, t}+\left(1-D R_{t}\right) \cdot \sum_{i=0}^{n-1} \sum_{j=1}^{n-1} g_{i, j, t-1} \cdot \frac{j}{j+1} .
$$

Deriving $D R_{t}$ from (3) and (4) was complicated by the fact that data for neither $\sum_{i=0}^{n-1} \sum_{j=1}^{n-1} b_{i, j, t-1}, \sum_{i=0}^{n-1} \sum_{j=1}^{n-1} g_{i, j, t-1}$, or $\sum_{j=1}^{n-1} g_{0, j, t}$ are publicly available.

One way to overcome the problem of unobservable cohorts of the portfolio's loans was to calibrate the term structure using information about the maximum available maturity of loans, the growth rate of loans, the NPL ratio, and the distribution of new loans entering the portfolio in each period. Then, the rate of default can be recursively computed from equation (3) as follows:

$$
D R_{t}=\frac{\left(\sum_{i=0}^{n-1} \sum_{j=1}^{n} b_{i, j, t}\right)-\left(\sum_{i=0}^{n-1} \sum_{j=1}^{n-1} \tilde{b}_{i, j, t-1}\right)}{\sum_{i=0}^{n-1} \sum_{j=1}^{n-1} \tilde{g}_{i, j, t-1}},
$$

where $\tilde{b}_{i, j, t-1}$ and $\tilde{g}_{i, j, t-1}$ are the approximated values of true $b_{i, j, t-1}$ and $g_{i, j, t-1}$, respectively, derived from equations (3) and (4) for the time $t-1$. The initial values of $b_{i, j, 0}$ and $g_{i, j, 0}$ as well as the new loans $g_{0, j, t}$ should be either known or assumed. In the latter case, Serwa (2013) proposed to use some artificial distributions of initial loans in the portfolio and to perform robustness analysis afterwards.

We considered two distributions of new loans with respect to their maturity. The first approach assumed that all new loans were equally distributed across maturities. In this approach, the value of new one-year loans was equal to the value of ten-year loans. The second approach controlled for when new long-term loans were more frequent than new short-term loans and the distribution of new loans was triangular. The one-period loans were $n$ times less frequent than the $n$-period loans, and the values of loans with respective maturities were all calibrated with the initial growth rate of a total loan portfolio and the initial ratio of the NPLs. The two distributions described here were used in our empirical analysis. 
When calibrating the distribution of good and bad loans in the portfolio to match the initial ratio of NPLs, we recursively calculated the long-term levels of $b_{i, j, t}$ and $g_{i, j, t}$ for $t$ approaching infinity assuming a steady state growth rate of the whole portfolio, a constant distribution of new loans with respect to maturity, and a constant rate of default of loans. In practice, 500 recursive computations of $b_{i, j, t}$ and $g_{i, j, t}$ from equations (3) and (4) lead to stable steady state values of these variables for all $i$ and $j$ independently of the initial values (cf., Serwa, 2013).

\section{Default rates of housing loans in nine European economies}

We looked at nine European banking sectors, and we were able to obtain information on NPL ratios, the growth rates of loans, and the values of maximum available (but realistic) maturity for all loans in each sector. We chose to focus on the aggregate portfolios of housing loans in each country, because these loans have long maturities and are more homogenous than other types of loans. The countries we analyzed were the Czech Republic, Greece, Hungary, Ireland, Latvia, Poland, Portugal, Romania, and Spain. The sample began in 2002 and ended in 2009 for the Czech Republic, and ranged from 2004-2010 for Hungary (both samples contain annual data). For other countries, the data are quarterly and equal: 2005 Q1-2011 Q4 for Greece; 2009 Q3-2011 Q3 for Ireland; 2007 Q3-2011 Q4 for Latvia; 2004 Q4-2011 Q4 for Poland; 1998 Q1-2012 Q2 for Portugal; 2008 Q3-2011 Q4 for Romania; 1999 Q1-2012 Q1 for Spain.

The data on NPL rates came from the central banks in each respective country. Unemployment rates, wage growth rates, and market interest rates (usually the short-term interbank rates in respective markets) were obtained from the International Financial Statistics database of the International Monetary Fund.

Figures 1-9 present fluctuations of the NPL ratios in time and the intermediate changes in the business cycles of respective economies. For most of the countries, we observed rising unemployment and slowing income growth during the global financial crisis of 2008-2009. In the calm periods wage growth was higher and the unemployment rate was lower. By observing NPL ratios, it was difficult to distinguish between crisis and non-crisis periods because they contained combined information about credit growth rates and credit DRs. These two combined factors provided rather noisy messages on credit risk. For instance, the pace of credit growth in many countries was still high at the beginning of the recent global financial crisis while the economic fundamentals were already weak and the credit risk was rising.

Loan DRs should react more rapidly to changing economic conditions than the NPL ratios. Figures 10-18 present changes in DRs for each analyzed country. These DRs were calibrated 
using the model presented in Section 1. The DRs shown in these figures are computed using of equation (5) and are valid for the two scenarios: (a) when all new loans are equally distributed across remaining maturities (DR1); (b) when more new loans have longer-term maturities (DR2). The differences between the two estimates were relatively small and they did not affect the general conclusions (other distributions of new loans in the portfolio were also possible, but they did not significantly change the results).

There were strong differences in the volatility and roughness of the calibrated DRs for different countries. For some countries such as Hungary, Latvia, or Spain, the estimates were relatively smooth. The series for Portugal and Poland were much rougher. These latter DRs may contain more economic information or they may simply contain more random noise. It is clear from the figures that large increases in DRs were observed during the global financial crisis of 2008-2009 for all the countries (this applied to Greece later as well). For some countries (such as Spain) the crisis period was also the most volatile in terms of changes in the DRs.

Surprisingly, DRs became very small values in calm periods for some markets (such as Latvia). The rates of default were also rather small for most portfolios, which seems unlikely even for developed economies in prosperous times. Therefore, the calibrated indices should be treated as proxies of credit risk rather than precise estimates of credit risk. Our new measures are likely to provide valuable information on changes of credit risk over the business cycle rather than the information on the levels of risk.

In the Czech Republic, the DRs are on average 50 percent lower before the crisis. A similar result was found in Hungary where the DR started to increase in 2008 and was six times higher in 2010 than it was in 2007. In Greece, the lowest rates of default were observed in the years 2006 and 2007. These rates doubled during the crisis of 2008-2009 and even quadrupled in the year 2011. In the short sample of Irish data, the DR grew steadily over the 2008-2009 crisis and in the post-crisis period, which suggests a negative effect on Irish households during the sovereign debt crisis in the euro zone. In Latvia and in Spain, one can observe the single peak of the rate of default in the middle of the global financial crisis. Such a peak was also apparent for Poland, but in a much noisier neighborhood of similar peaks in 2004, 2006, and 2011. In turn, the crisis period for Romania and Portugal was difficult to distinguish from other times when using the DR time series.

We investigated how our measure of credit risk was correlated with macroeconomic factors, and the results are shown in Table 1 . We found that DRs were often strongly correlated with macroeconomic variables in the investigated samples. The patterns of correlation were not perfectly clear, however, and they strongly depended on the investigated countries. It is interesting to note that the DRs measured at time $t$ were more correlated with the unemployment rates in the upcoming quarter (measured at time $t+1$ ) rather than those measured in the present quarter (at time $t$ ) in six out of nine cases. For the growth of wages, correlations were more negative between present defaults and the future growth of wages in five out of 
nine cases. Similarly, correlations were more negative between present defaults and the future interest rates in five out of nine cases. We expected a negative link between present DRs and future interest rates if central banks adjusted the interest rate to worsening or improving economic conditions proxied by DRs. We conclude that there is no strong evidence that proves DRs rates can predict macroeconomic variables very well; however, the contemporaneous linkages of credit risk and macroeconomic factors are strong in many countries.

We also tested for any evidence of pairwise Granger causality between macroeconomic variables and the DR. The results are presented in Table 2 only for the countries where enough time-series data were available. Our results confirmed the outcomes from the correlation analysis and suggested that there was no clear direction of lagged causality between the analyzed variables.

\section{Conclusions}

Deriving probabilities of default from raw indices of NPLs is a difficult task when only limited information is available. Depending on the country, the computed DRs are volatile or smooth, but are always more irregular than original NPL ratios. This may suggest that economic fluctuations and their effects on the loan quality are volatile. Banks tend to smooth their economic performance (and the NPL ratio) by controlling their loan supply. There are several factors that influence changes in the NPL ratios independently of the changing rates of default. For example, selling some parts of a loan portfolio will significantly affect the termstructure of the aggregate loan portfolios. Changing accounting regulations, and changing policies of banks with respect to new loan supply and old NPLs would also affect the results. In practice, more information about the structure of the loan portfolio improves the precision of calibrated DRs.

Further analyses should compare our proxy of credit risk for a loan portfolio with the true values of DRs in bank loan portfolios. This task is complicated by the fact that few banks publish estimates of PDs cyclically.

One direct extension of our results could be regression analyses of macroeconomic factors affecting credit risk in different countries. It is possible that the combined macroeconomic variables in regression models may explain a large share of credit-risk volatility. This may lead to more efficient models used to predict credit risk, and our Granger causality analysis represents a first step in this direction.

\section{Acknowledgements}

This research has been financed by the National Centre of Science (grant no. OPUS 2012/07/ B/HS4/00361). We would like to thank seminar participants at the European Central Bank, 
Narodowy Bank Polski, Warsaw School of Economics, FRAP 2015 conference participants in Steyr, and an anonymous referee for valuable comments to this paper.

\section{References}

Aman, H. and Miyazaki, H. (2009). Valuation effects of new equity issues by banks: evidence from Japan. Applied Financial Economics, 19(8):635-645.

Čihák, M. and Schaeck, K. (2010). How well do aggregate prudential ratios identify banking system problems? Journal of Financial Stability, 6(3):130 - 144.

Coricelli, F., Mucci, F., and Revoltella, D. (2006). Household Credit in the New Europe: Lending Boom or Sustainable Growth? CEPR Discussion Papers 5520, C.E.P.R. Discussion Papers.

Festić, M., Repina, S., and Kavkler, A. (2009). The Up-Coming Crisis and the Banking Sector in the Baltic States. Swiss Journal of Economics and Statistics (SJES), 145(III):269-291.

Hasan, I. and Wall, L. D. (2004). Determinants of the Loan Loss Allowance: Some CrossCountry Comparisons. Financial Review, 39(1):129-152.

Jin, J. Y., Kanagaretnam, K., and Lobo, G. J. (2011). Ability of accounting and audit quality variables to predict bank failure during the financial crisis. Journal of Banking and Finance, 35(11):2811 - 2819.

Lízal, L. and Svejnar, J. (2002). Investment, Credit Rationing, And The Soft Budget Constraint: Evidence From Czech Panel Data. The Review of Economics and Statistics, 84(2):353-370.

Meeker, L. G. and Gray, L. (1987). A note on non-performing loans as an indicator of asset quality. Journal of Banking and Finance, 11(1):161 - 168.

Mendoza, E. G. and Terrones, M. E. (2008). An Anatomy Of Credit Booms: Evidence From Macro Aggregates And Micro Data. NBER Working Papers 14049, National Bureau of Economic Research, Inc.

Pinto, R. L. and Vivan, G. F. A. (2013). Converting the NPL Ratio into a Comparable Long Term Metric. Working Papers Series 309, Central Bank of Brazil, Research Department.

Podpiera, R. (2006). Does Compliance with Basel Core Principles Bring Any Measurable Benefits? IMF Staff Papers, 53(2):5. 
Serwa, D. (2013). Measuring Non-Performing Loans During (and After) Credit Booms. Central European Journal of Economic Modelling and Econometrics, 5(3):163-183.

Tornell, A. and Westermann, F. (2002). Boom-Bust Cycles in Middle Income Countries: Facts and Explanation. NBER Working Papers 9219, National Bureau of Economic Research, Inc.

Whalen, G. W. (2010). Are Early Warning Models Still Useful Tools for Bank Supervisors? Economics Working Paper 2010-3, Office of the Comptroller of the Currency, Washington DC. 
Figure 1: The NPL ratio and macroeconomic data for the Czech Republic

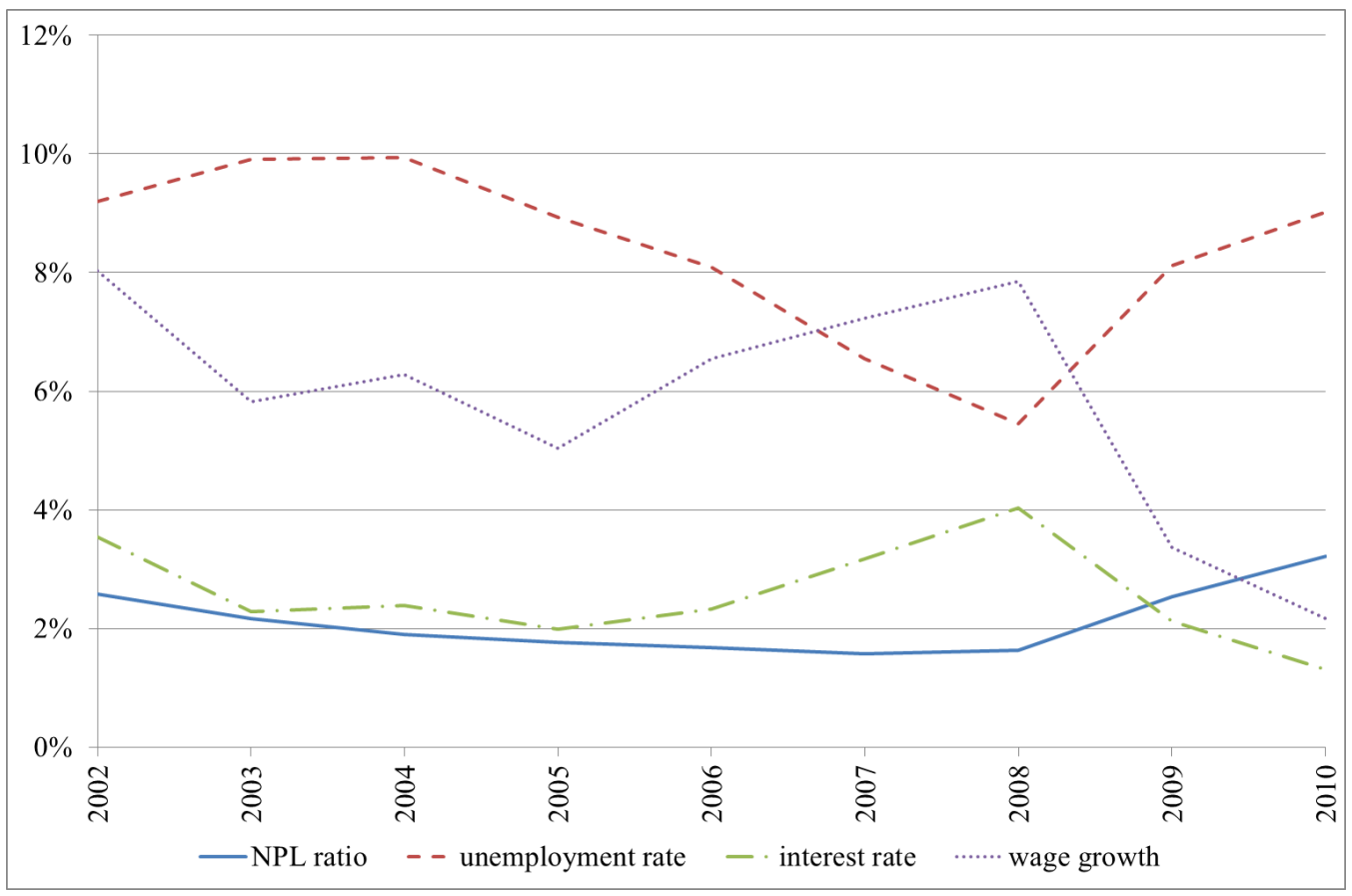

Figure 2: The NPL ratio and macroeconomic data for Greece

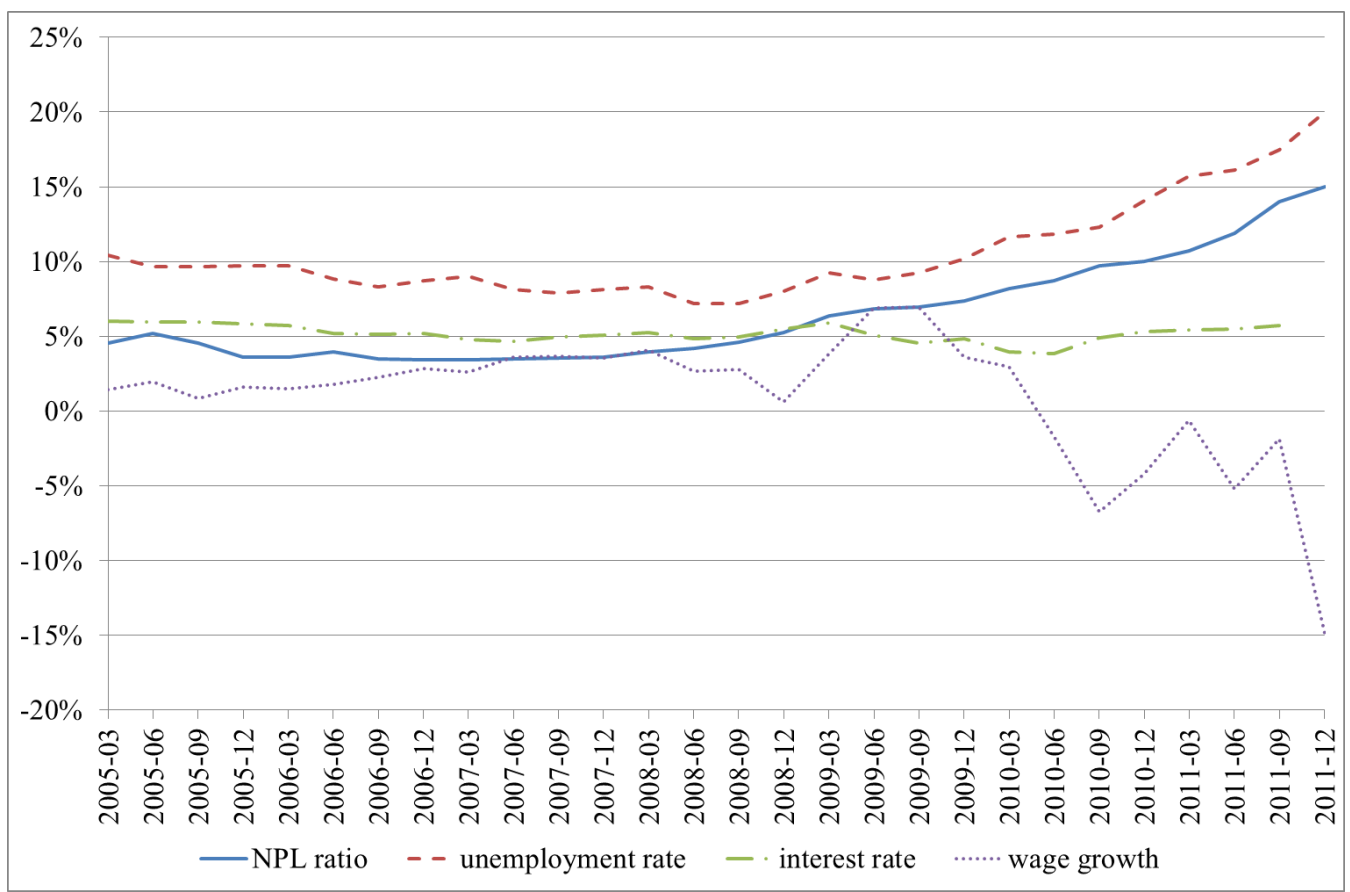


Figure 3: The NPL ratio and macroeconomic data for Ireland

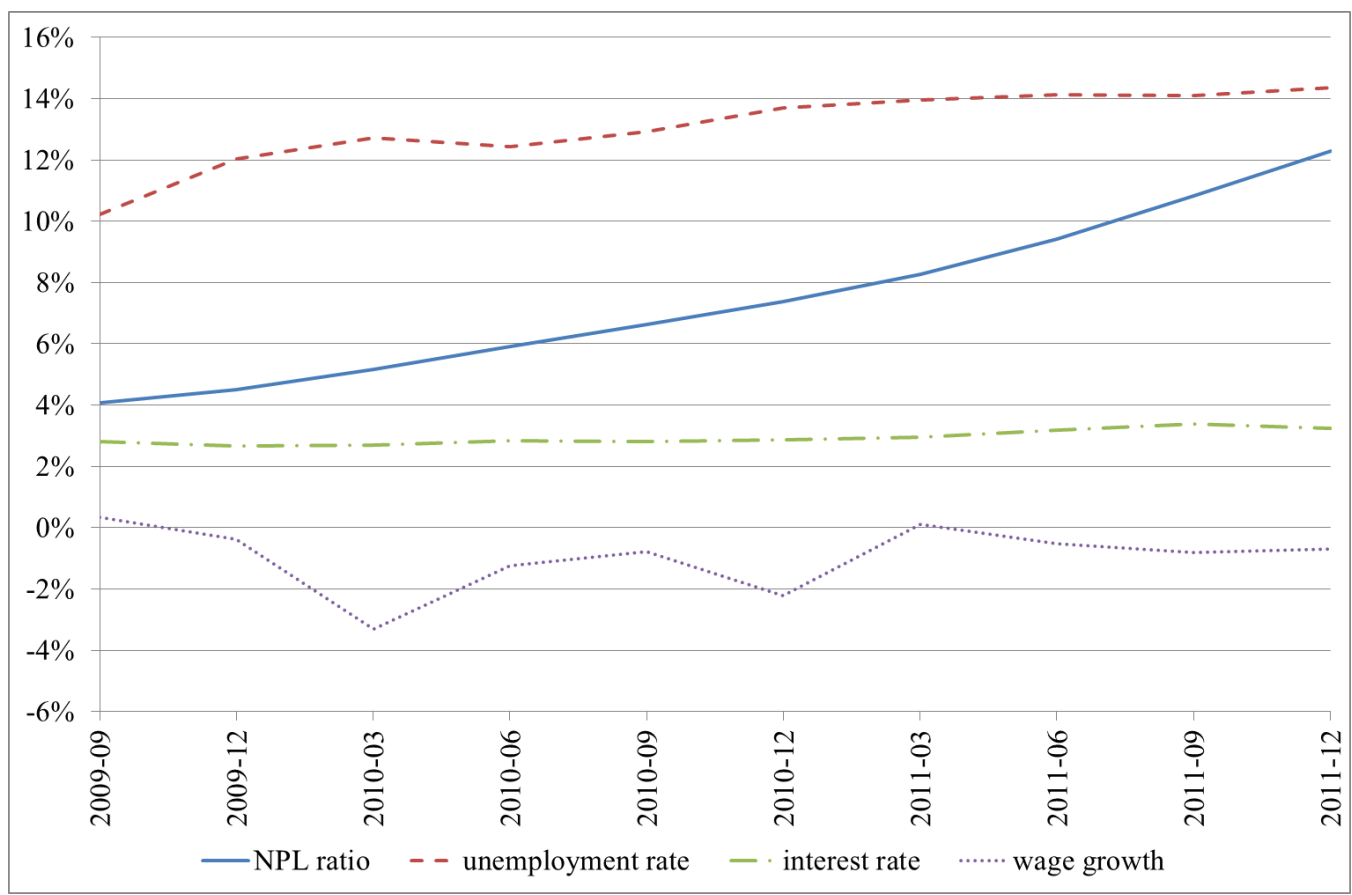

Figure 4: The NPL ratio and macroeconomic data for Hungary

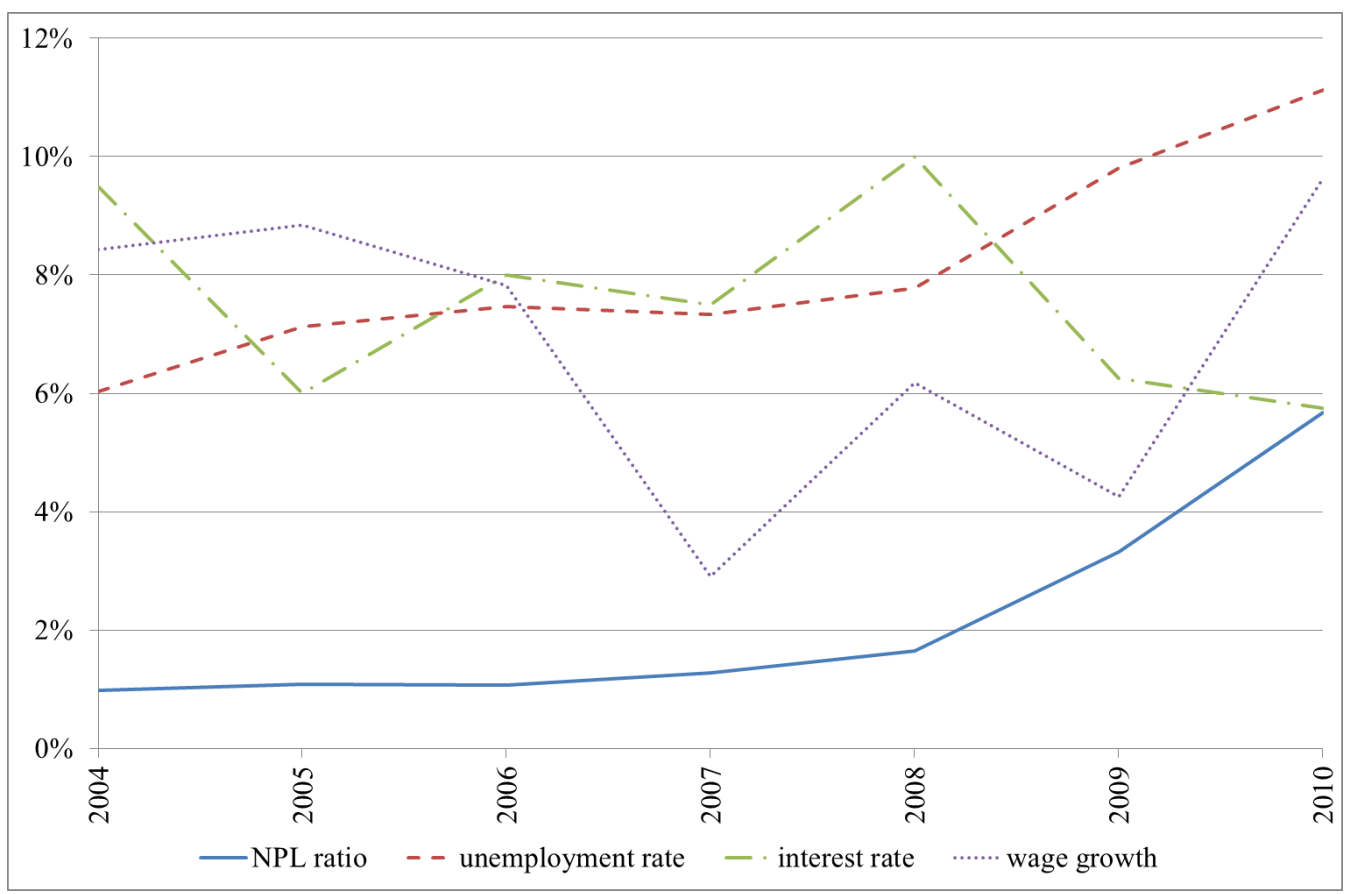


Figure 5: The NPL ratio and macroeconomic data for Latvia

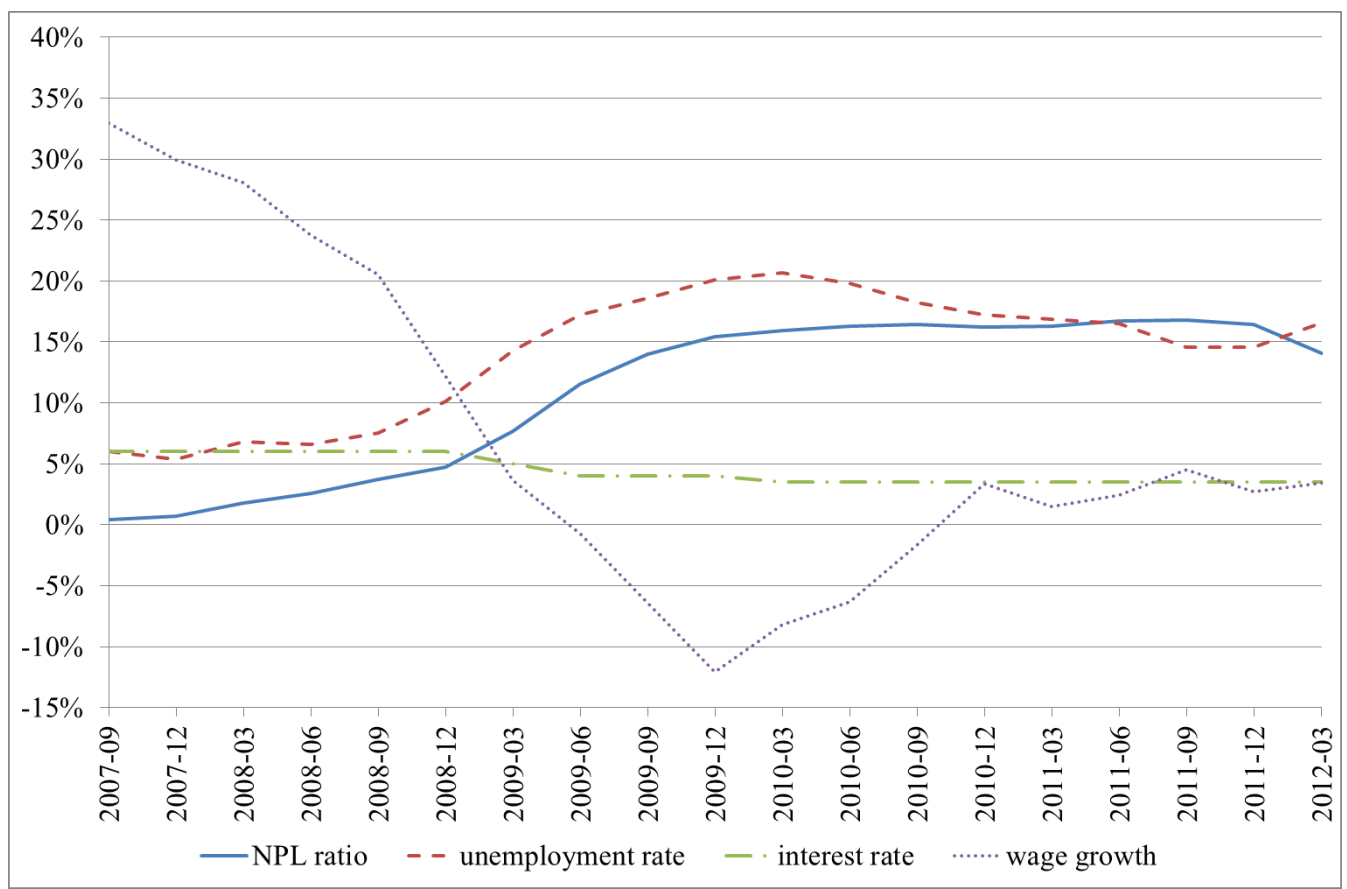

Figure 6: The NPL ratio and macroeconomic data for Poland

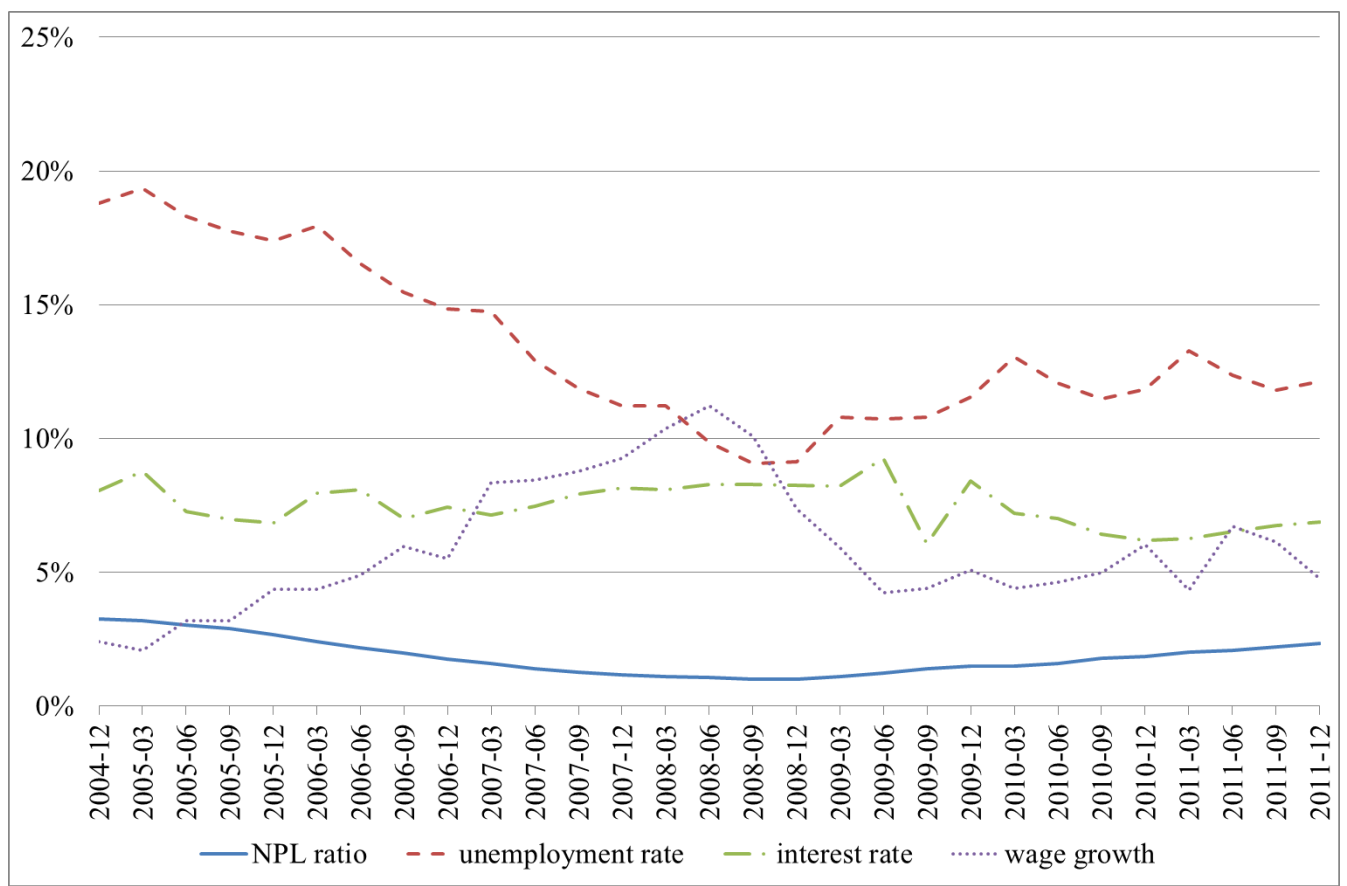


Figure 7: The NPL ratio and macroeconomic data for Portugal

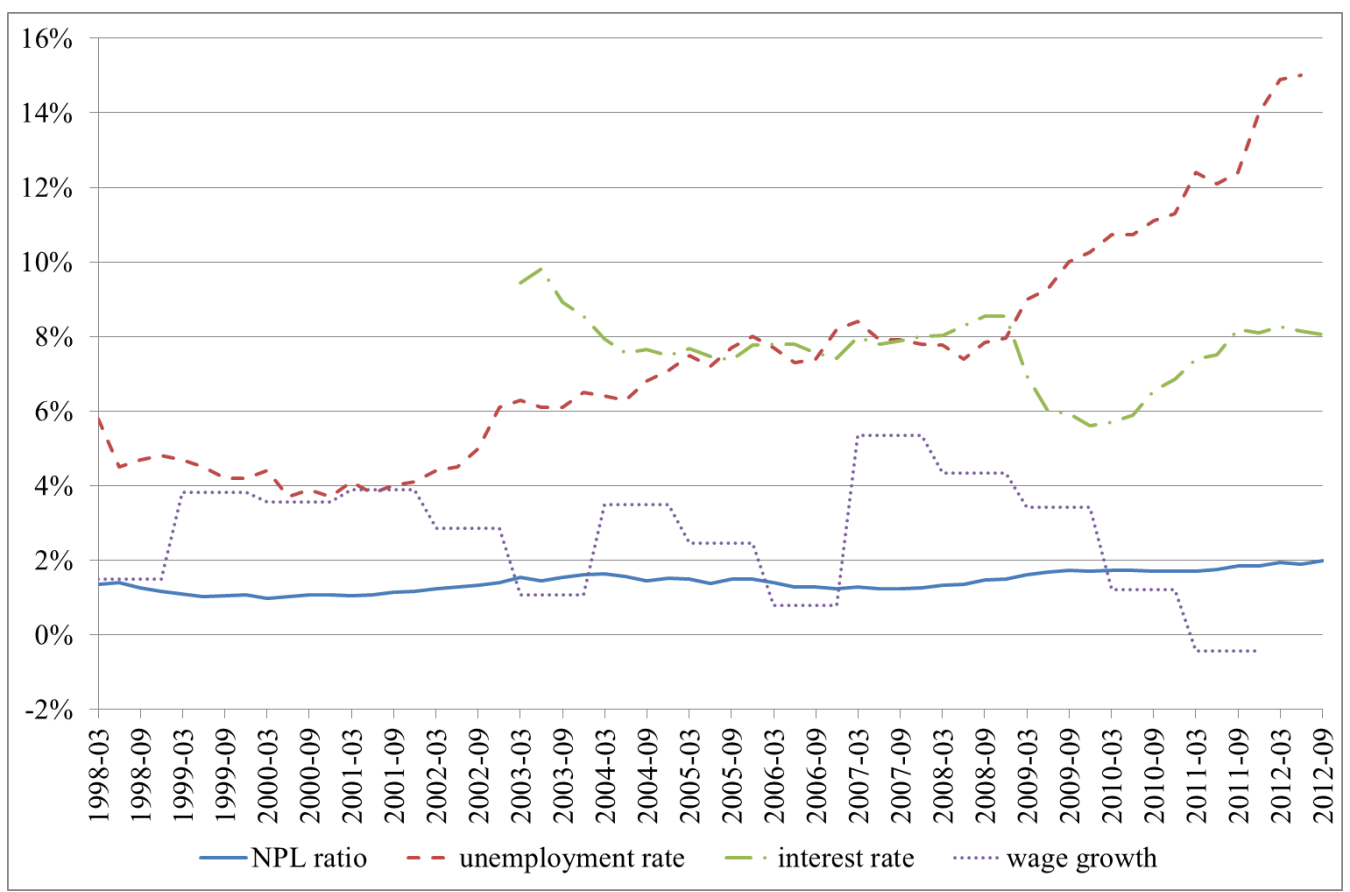

Figure 8: The NPL ratio and macroeconomic data for Romania

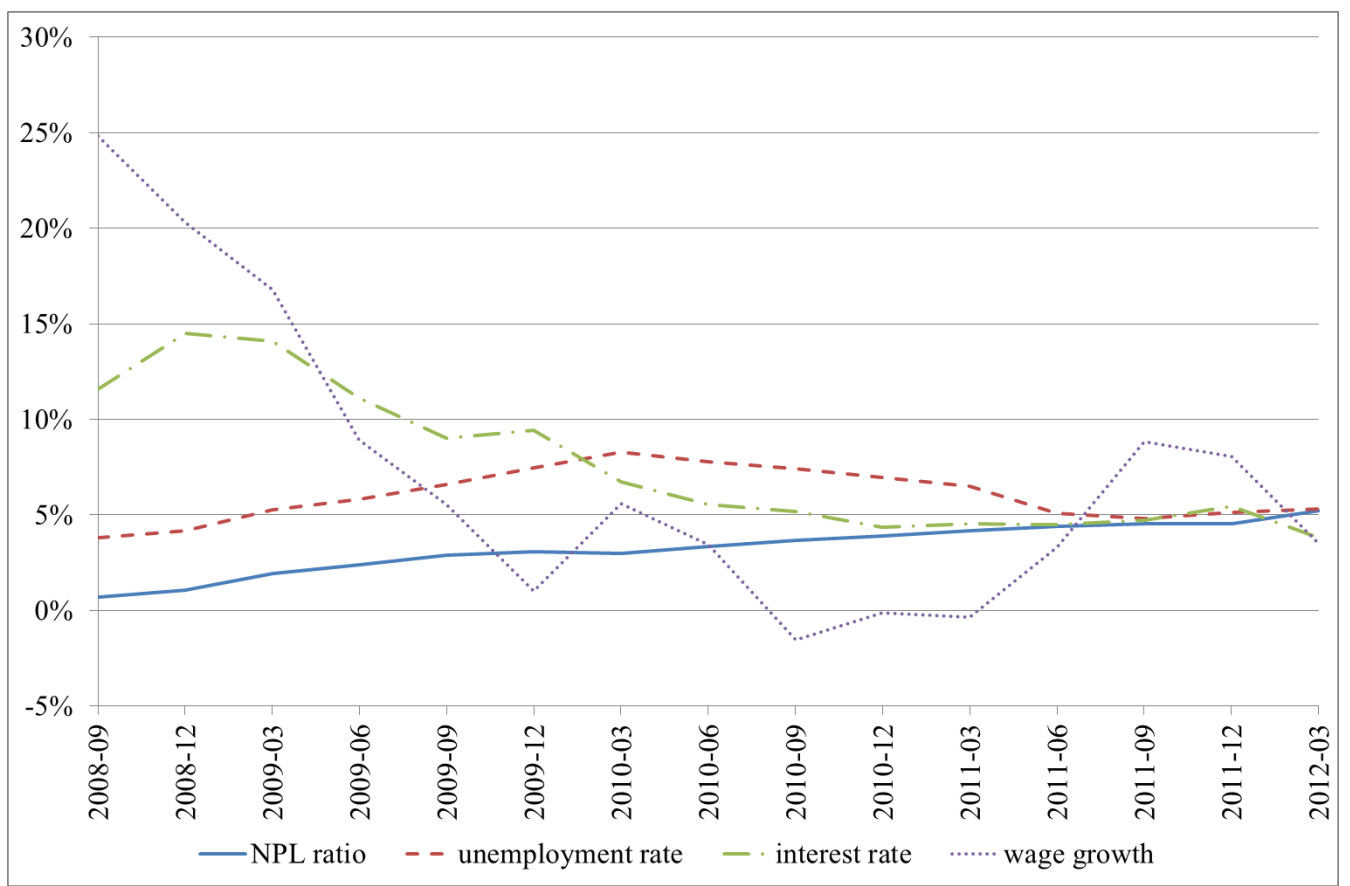


Figure 9: The NPL ratio and macroeconomic data for Spain

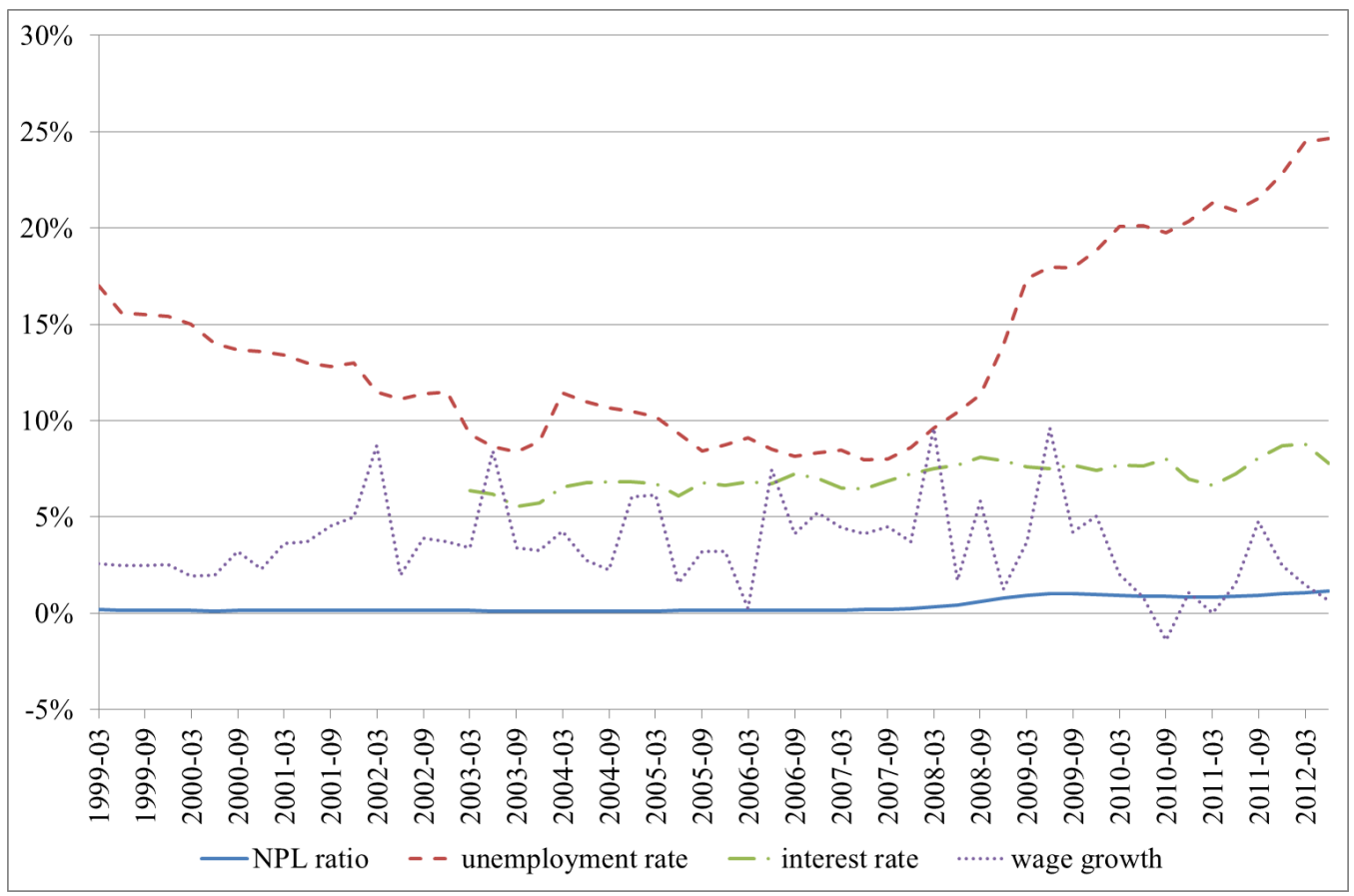

Figure 10: Calibrated DRs for the Czech Republic

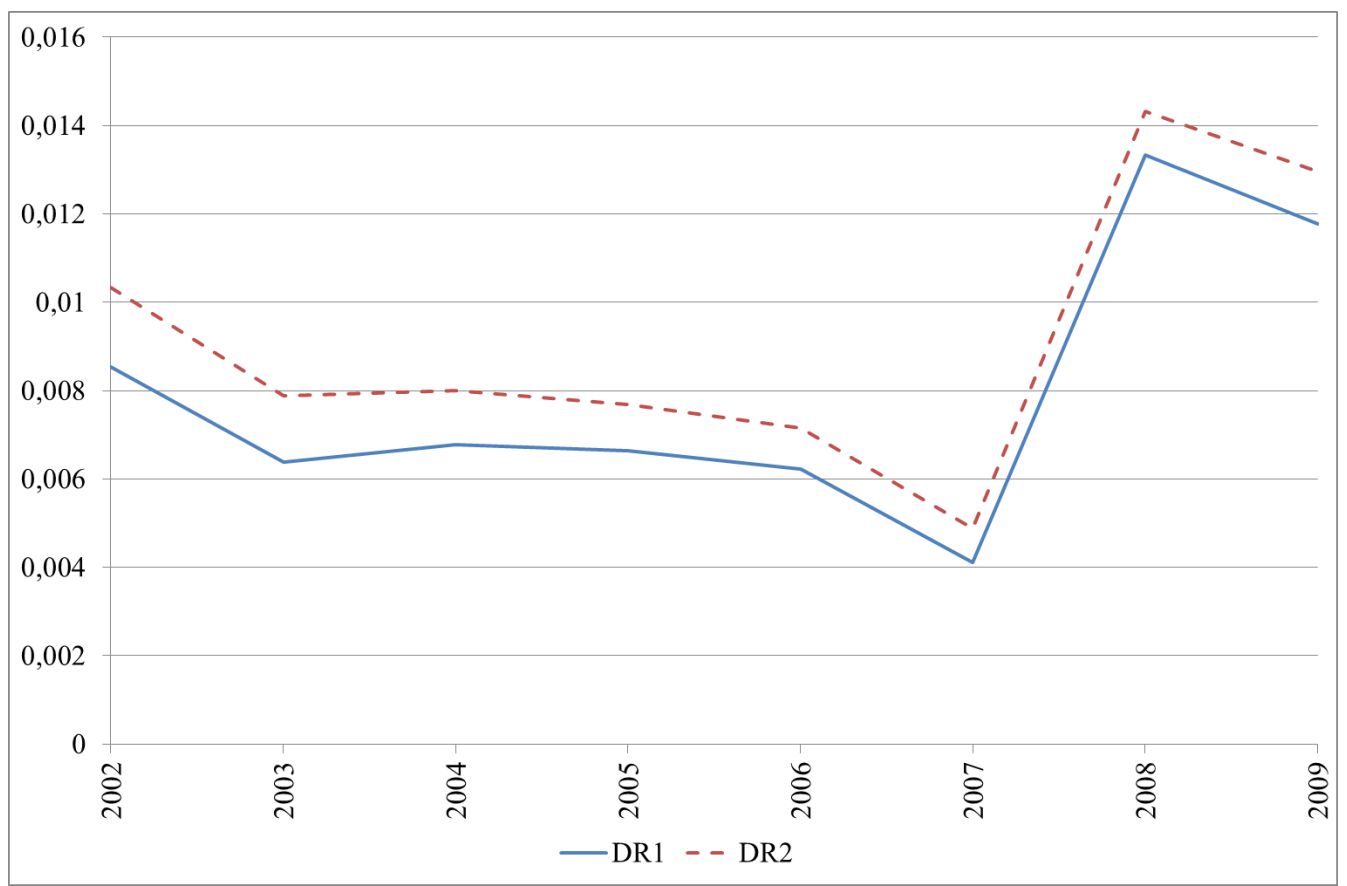


Figure 11: Calibrated DRs for Greece

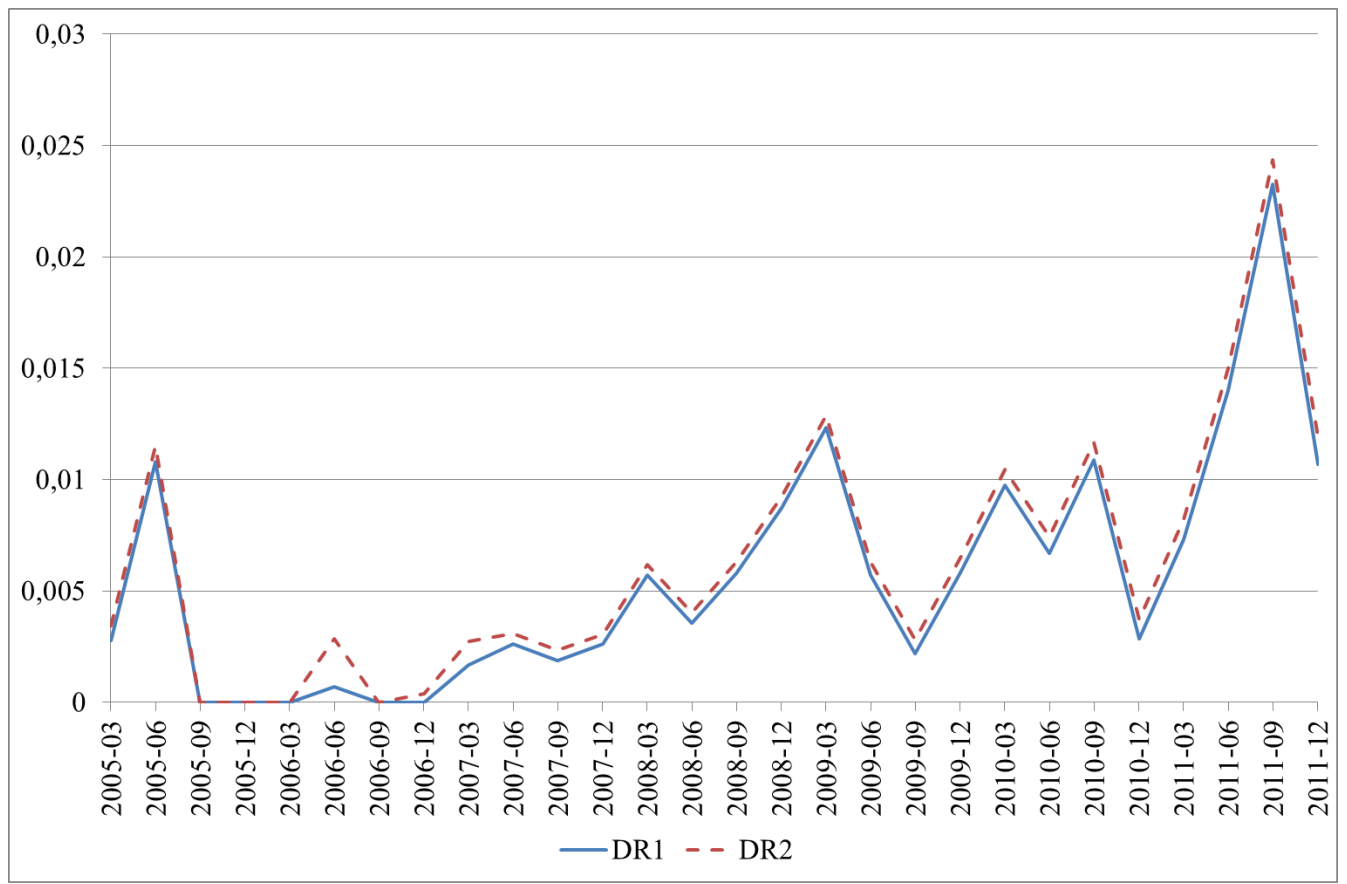

Figure 12: Calibrated DRs for Ireland

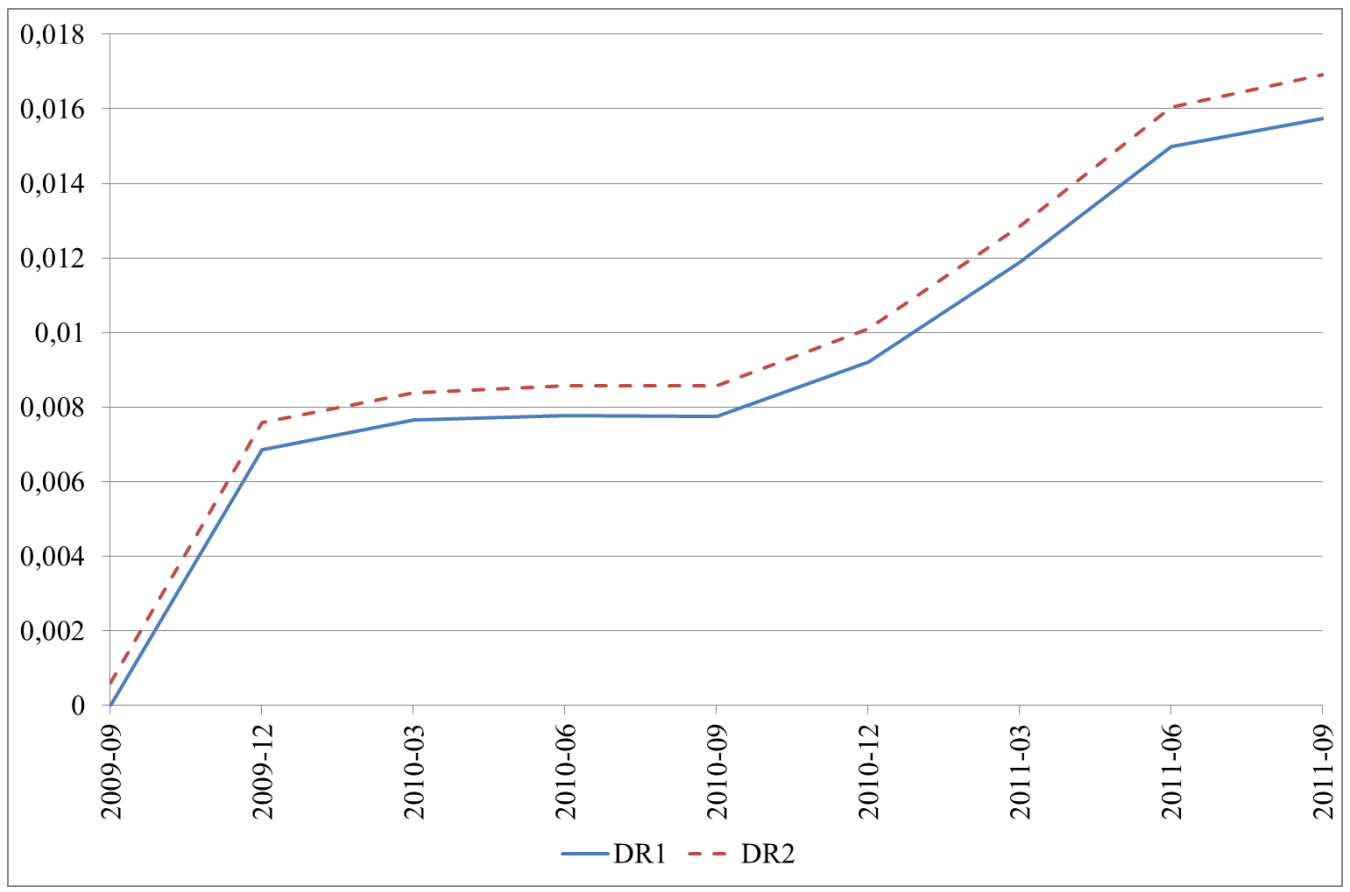


Figure 13: Calibrated DRs for Hungary

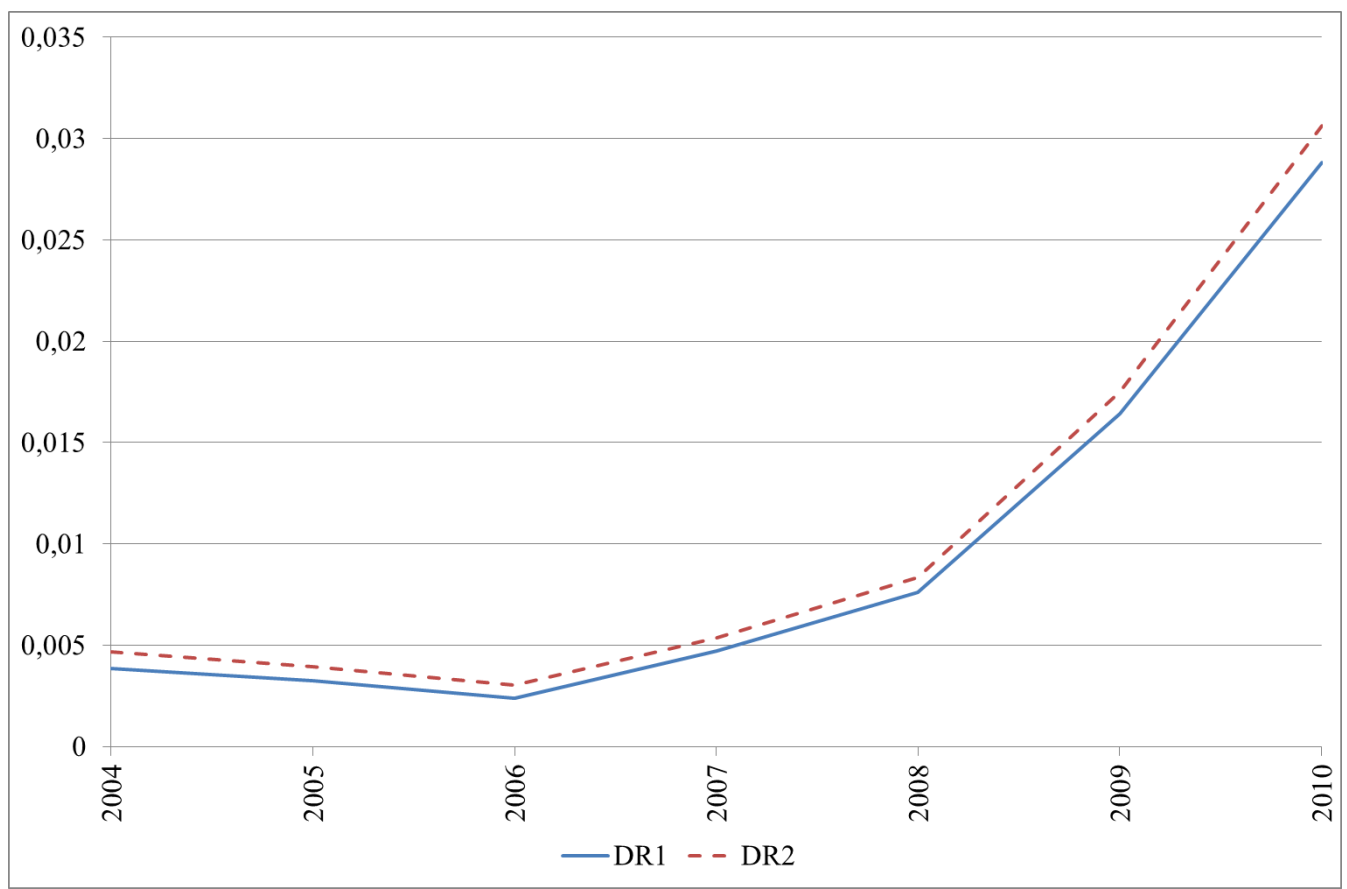

Figure 14: Calibrated DRs for Latvia

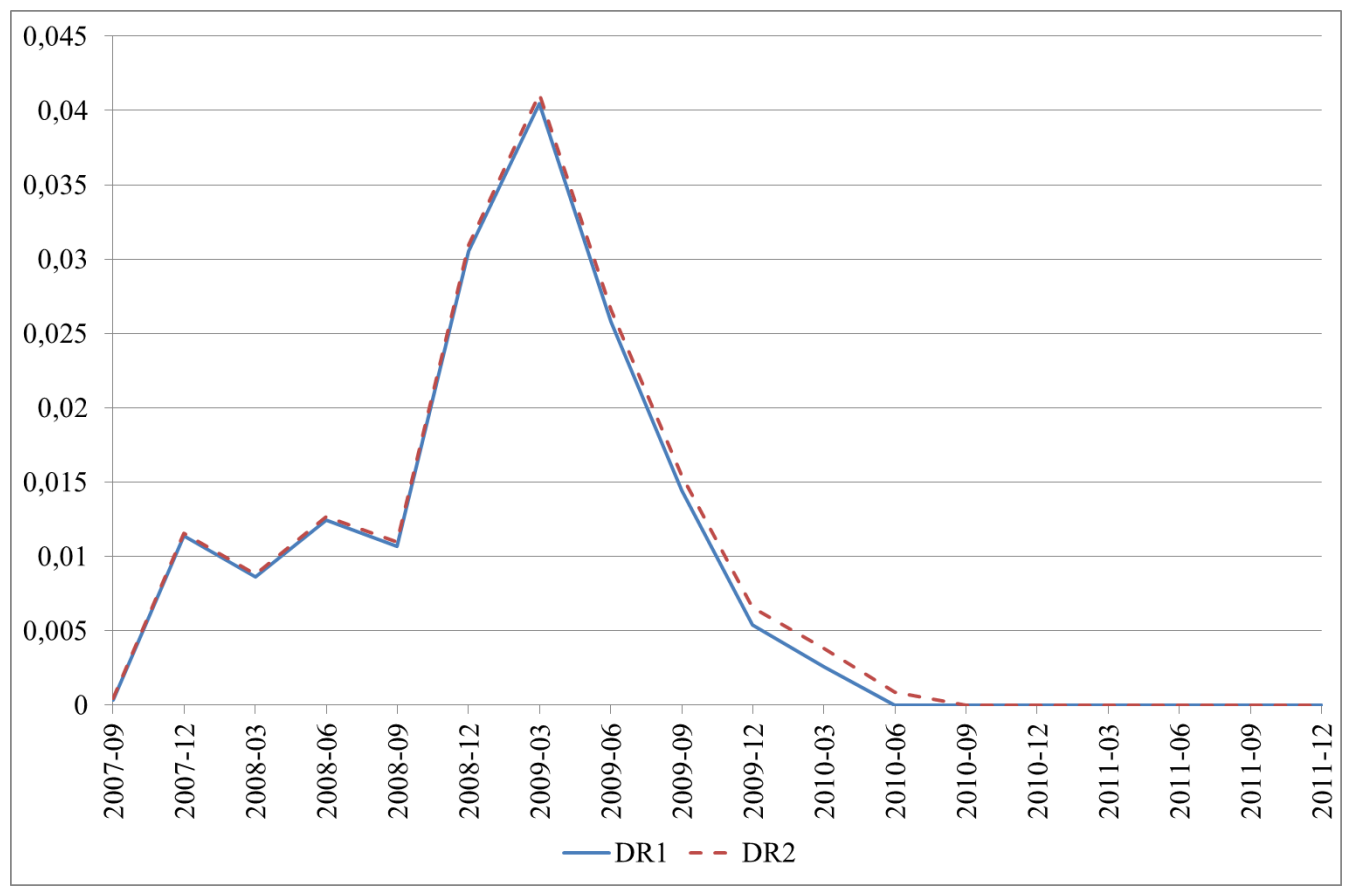


Figure 15: Calibrated DRs for Poland

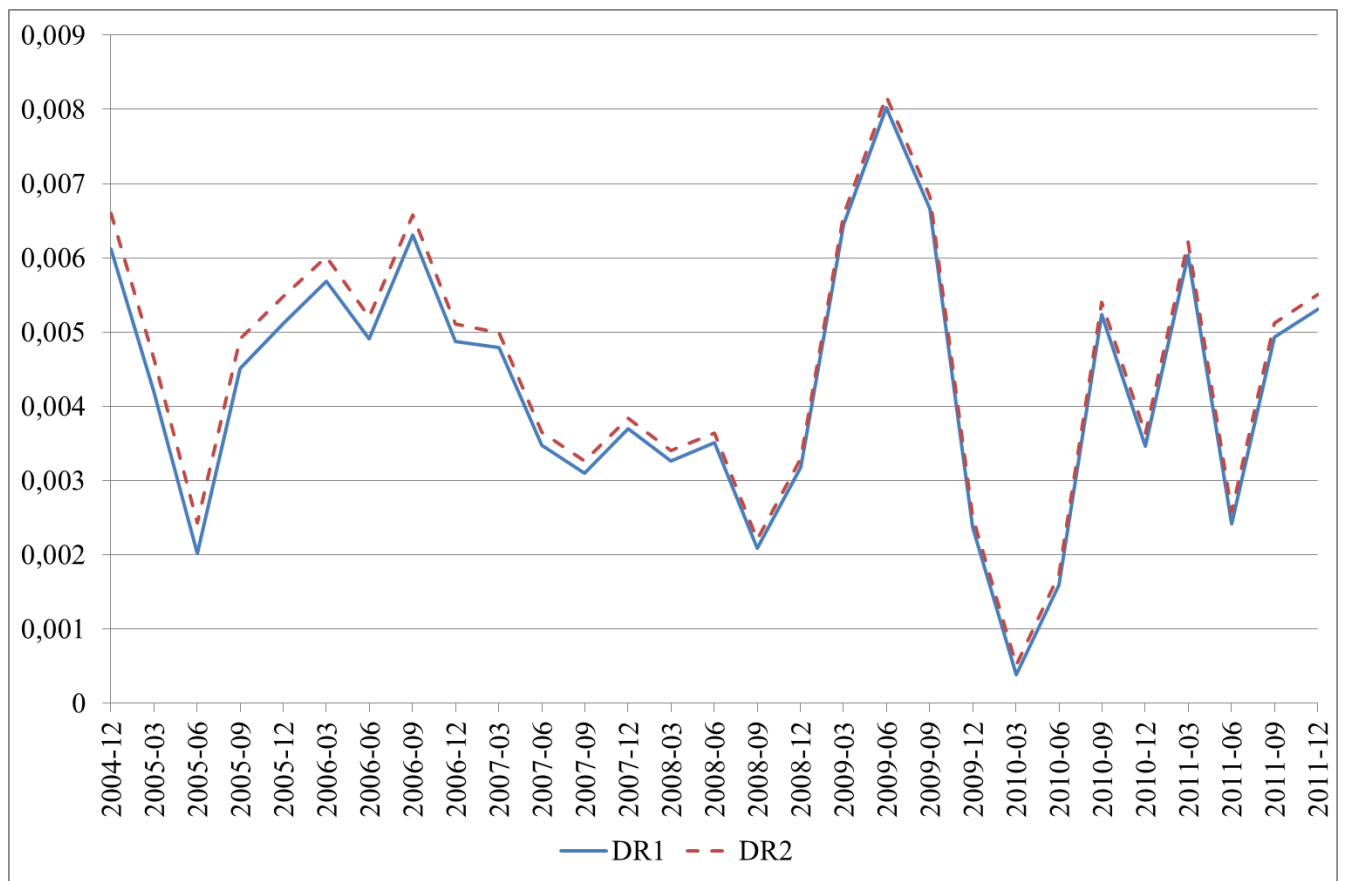

Figure 16: Calibrated DRs for Portugal

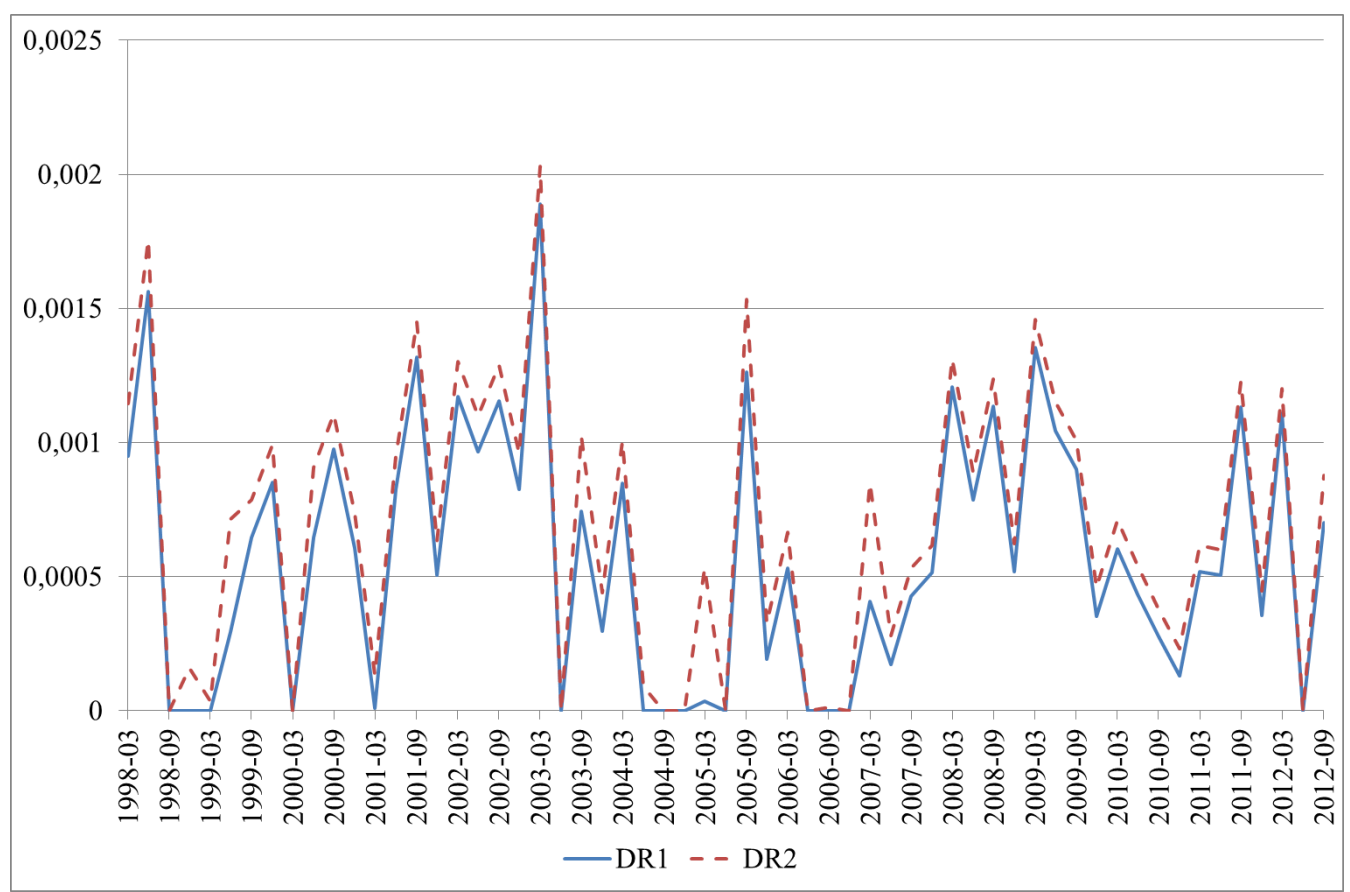


Figure 17: Calibrated DRs for Romania

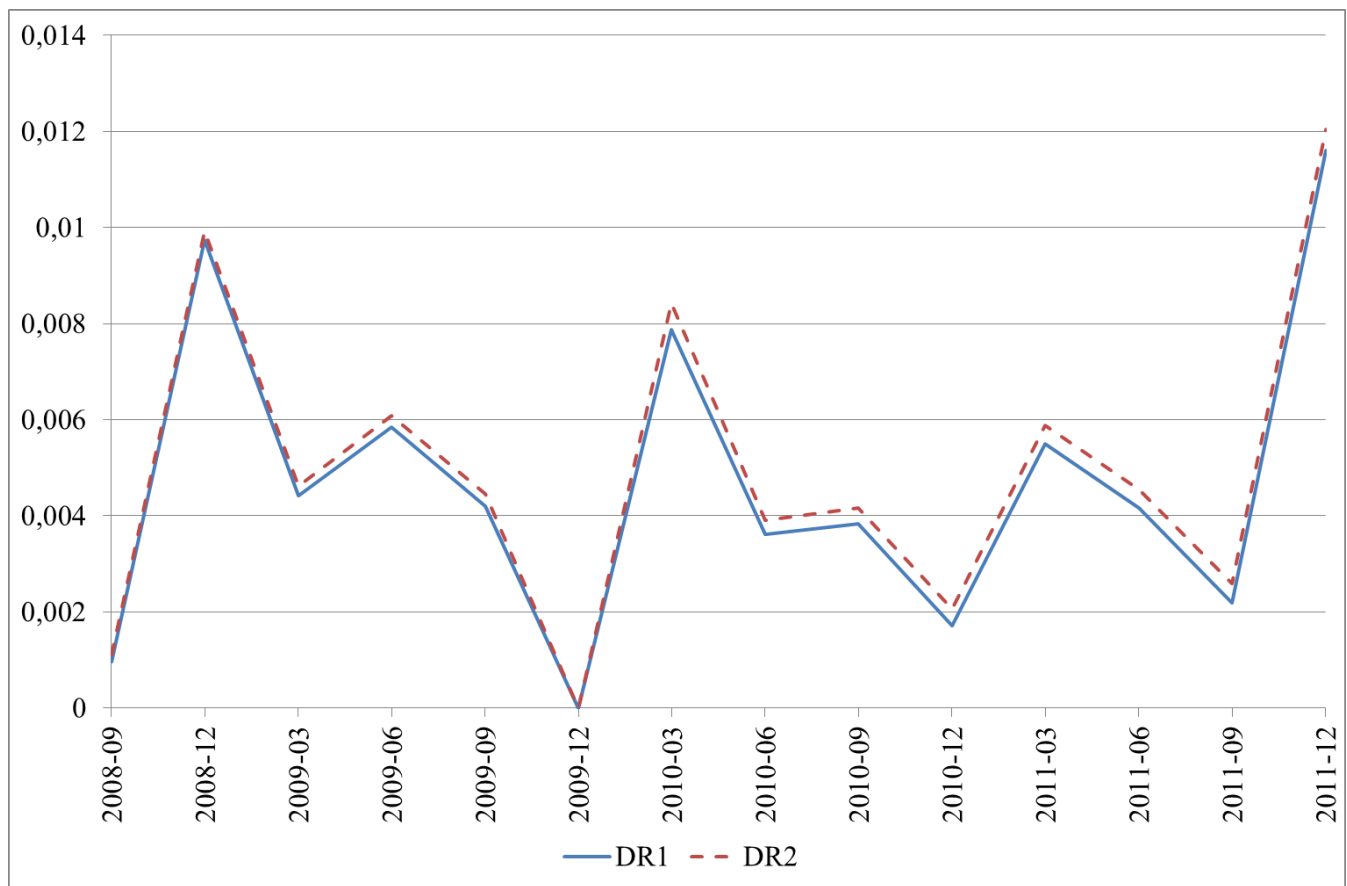

Figure 18: Calibrated DRs for Spain

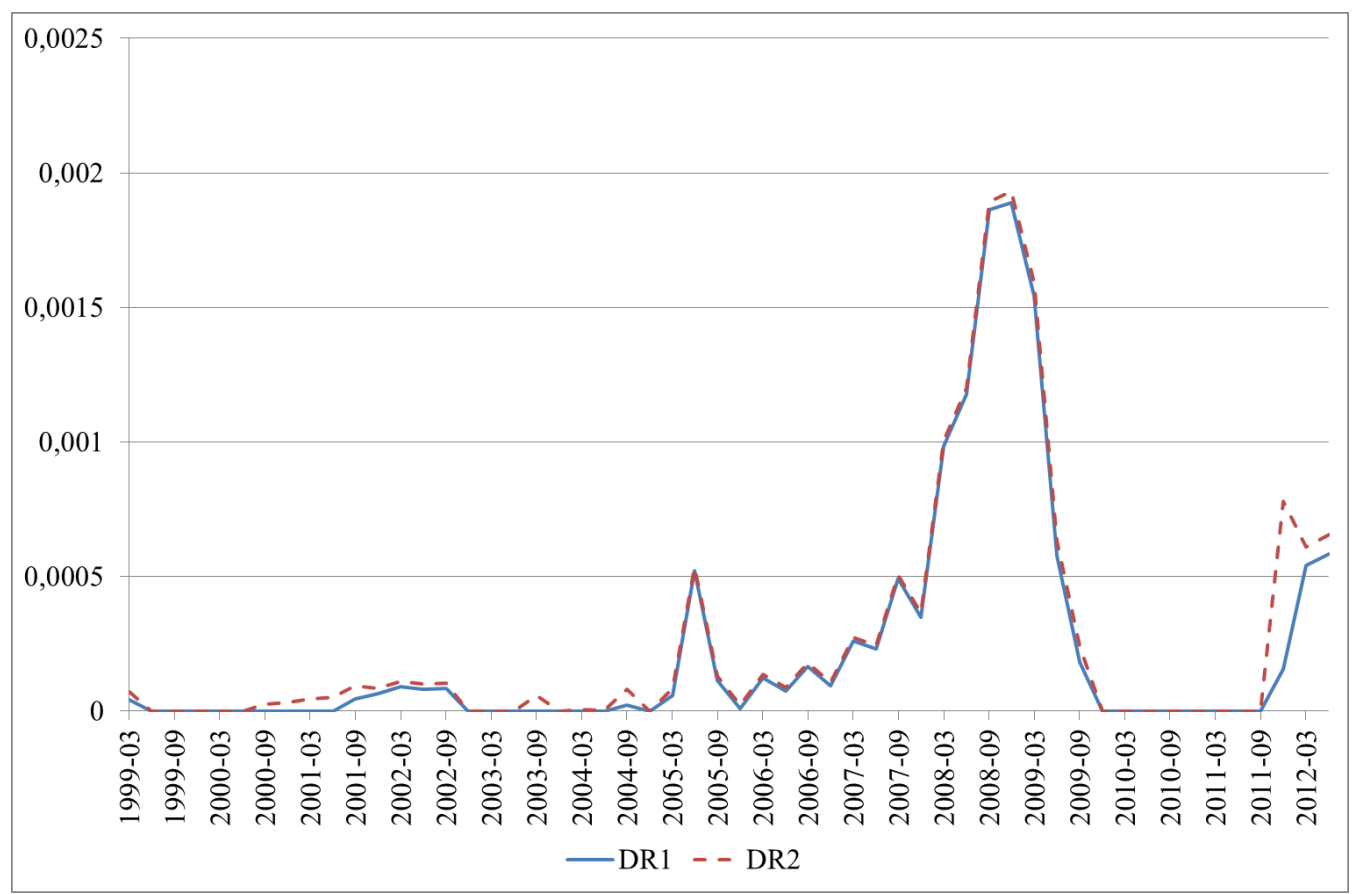


Table 1: Correlations of loan DRs with NPL ratios and macroeconomic variables

\begin{tabular}{|l|c|c|c|c|c|c|c|c|}
\hline & $\begin{array}{c}\text { NPL } \\
(t)\end{array}$ & $\begin{array}{c}\text { NPL } \\
(t+1)\end{array}$ & $\begin{array}{c}\text { unemployment } \\
\text { rate } \\
(t)\end{array}$ & $\begin{array}{c}\text { unemployment } \\
\text { rate } \\
(t+1)\end{array}$ & $\begin{array}{c}\text { wage } \\
\text { growth } \\
(t)\end{array}$ & $\begin{array}{c}\text { wage } \\
\text { growth } \\
(t+1)\end{array}$ & $\begin{array}{c}\text { interest } \\
\text { rate } \\
(t)\end{array}$ & $\begin{array}{c}\text { interest } \\
\text { rate } \\
(t+1)\end{array}$ \\
\hline Czech Rep. & 0.32 & 0.87 & -0.40 & 0.40 & -0.10 & -0.91 & 0.39 & -0.72 \\
\hline Greece & 0.75 & 0.77 & 0.62 & 0.65 & -0.40 & -0.62 & 0.10 & 0.04 \\
\hline Ireland & 0.92 & 0.93 & 0.94 & 0.87 & -0.07 & 0.15 & 0.79 & 0.91 \\
\hline Hungary & 1.00 & 0.98 & 0.95 & 0.86 & 0.19 & 0.40 & -0.53 & -0.30 \\
\hline Latvia & -0.42 & -0.26 & -0.20 & 0.04 & 0.09 & -0.12 & 0.45 & 0.24 \\
\hline Poland & 0.17 & 0.14 & 0.17 & 0.20 & -0.30 & -0.18 & 0.00 & 0.08 \\
\hline Portugal & 0.10 & 0.10 & -0.07 & -0.01 & 0.07 & -0.01 & 0.10 & 0.10 \\
\hline Romania & 0.03 & 0.20 & -0.15 & -0.16 & 0.16 & 0.01 & 0.10 & -0.02 \\
\hline Spain & 0.33 & 0.41 & -0.01 & 0.06 & 0.10 & 0.15 & 0.42 & 0.37 \\
\hline
\end{tabular}

Note: DRs are measured at time $t$ while the other variables are measured at time $t$ or $t+1$ (as denoted in the first row).

Table 2: Granger causality tests between macroeconomic variables and the DR

\begin{tabular}{|l|c|c|c|}
\hline & $\begin{array}{c}\text { unemployment } \\
\text { rate }\end{array}$ & $\begin{array}{c}\text { interest } \\
\text { rate }\end{array}$ & $\begin{array}{c}\text { wage } \\
\text { growth }\end{array}$ \\
\hline Greece & - & & + \\
\hline Latvia & -+ & -+ & -+ \\
\hline Poland & & & \\
\hline Portugal & & & \\
\hline Spain & + & & \\
\hline
\end{tabular}

Note: The symbol + denotes Granger causality from the DR to the respective macroeconomic variable. The symbol - denotes Granger causality from the respective macroeconomic variable to the DR. Empty cells denote no causality in any direction. All tests use the $5 \%$ level of significance. 